Original Contribution

\title{
SUBSTITUTION OF SILVER-THIOSULFATE (STS) WITH SOME ESSENTIAL OILS ON VASE-LIFE OF CUT CARNATION CV. LIBERTY
}

\author{
A. Ebrahimzadeh ${ }^{1}$, M. B. Hassanpouraghdam ${ }^{1}$, F. Hashemi Hajikandi ${ }^{1}$, \\ M. A. Aazami Mavaloo' ${ }^{1}$ L. Vojodi Mehrabani ${ }^{2}$ \\ ${ }^{1}$ Department of Horticultural Sciences, University of Maragheh, Iran \\ ${ }^{2}$ Department of Agronomy and Plant Breeding, Azarbaijan Shahid Madani University, Iran
}

\begin{abstract}
Due to the huge side-effects of chemicals; essential oils have been considered as suitable alternatives for keeping the vase-life of cut flowers mainly owing to the availability and environment-friend nature of these bio-chemicals. In the present experiment, 50\% substitution of STS was achieved and tested on cut carnation flowers $c v$. Liberty by using the essential oils from four plants; Satureja sahendica Bornm., Echinophora platyloba DC., Tanacetum balsamita L. and Cupressus arizonica Greene., as CRD with five treatments and 3 replications. Vase-life and flower diameter were affected with $50 \%$ substitution of STS by essential oils from $C$. arizonica and T. balsamita. Membrane stability index, Malondialdehyde (MDA) content and Hydrogen peroxide $\left(\mathrm{H}_{2} \mathrm{O}_{2}\right)$ amounts were affected by the substitution treatments as well. The main preservative effect belonged to the substitution with $C$. arizonica. So that, $50 \%$ STS substitution with Cupressus oil holds the highest membrane integrity and the least data for MDA and $\mathrm{H}_{2} \mathrm{O}_{2}$ content.
\end{abstract}

Key words: Carnation, essential oil, vase life, Cupressus arizonica, Membrane stability index (MSI)

\section{INTRODUCTION}

Dianthus caryophyllus L. (Fam: Caryophyllaceae) holds the second production and supply of cut ornamental flowers worldwide $(1,2)$. Breeding methods and using some chemical and biological preservatives have been defined as the ways of choice for the increased longevity and vase life prolongation of cut flowers (1). Cut flowers treatments with ethylene-biosynthesis stoppers such as; aminoethoxy vinyl glycine, amino-oxi acetic acid, $\alpha$ amino-isobutric acid or with some ethylene action inhibitors such as STS and 1-methyl cyclopropane increase the vase life and durability of the flowers (3). Senescence in cut flowers is trigged by a cascade of physiobiochemical phenomena mainly the reduction in protein content due to protease activity, macro-molecules de-genesis, variation in plasma membrane intactness and integrity and increased transpiration (4). All these are traceable steps of variation in gene expression and protein biosynthesis (1). Antifungal, anti-

\footnotetext{
*Correspondence to: $M$. B. Hassanpouraghdam, Department of Horticultural Sciences, Faculty of Agriculture, University of Maragheh, 55181-83111 Iran, hassanpouraghdam@gmail.com
}

bacterial, antioxidant and overall strongbiological activities of plant-derived essential oils (5) have opened a new insight in the substitution of biogenic compounds instead of chemical ones in food, pharmaceutical and even in postharvest storage of agricultural crops. Standing on, identification and commercial usage of essential oils as biogenic environment-friend compounds with outstanding anti-microbial effects compared to chemical counterparts have been tried in the postharvest storage prolongation of several horticultural produce (6).

The main idea in the substitution of chemicals with biological ones is to maximize the damage control and to minimize the sideeffects of chemicals on human health and environment (7, 8). Essential oils have been caught the special attention in postharvest handling of cut flowers mainly due to their highlighted biological activities on microorganisms (9). Another report says that in cut carnation 'pink' flowers, the greatest vase life, relative fresh weight and the highest solution absorption were belonged to the flowers treated with lavender and thymus oils. 
It is worthy of note that, STS as a really effective compound in extending the vase life of cut flowers has been verified as an environment-unfriend chemical with several possible environmental and biological sideeffects especially in cases of huge commercial applications (10). The present experiment was conducted to assay the possible partial substitution and integrated application of STS with some essential oils on vase life and senescence pattern of cut carnation 'Liberty' cultivar.

\section{MATERIALS AND METHODS}

Cut carnation 'Liberty' flowers were afforded from a commercial greenhouse in Varamin city and were transported to Research Horticulture Laboratory at the University of Maragheh as dry translocation method. The cut flowers were screened based on visual and morphological characteristic to reach the homogenous pool for the experiment running. Flower stems were
EBRAHIMZADEH A., et al. cut inside water at $25 \mathrm{~cm}$ length. Laboratory conditions were $20 \pm 1{ }^{\circ} \mathrm{C}, 60-65 \% \mathrm{RH}$ and 12 hrs photoperiod during the experiment running. Essential oils of Satureja sahandica Bornm., Echinophora platyloba DC., Tanacetum balsamita L. and Cupressus arizonica Greene. were extracted by an all-glass Clevenger type apparatus according to European pharmacopoeia.

\section{Treatments:}

$0.1 \mathrm{mM}$ silver thio-sulphate was prepared by the combination of $\mathrm{AgNO}_{3}+\mathrm{Na}_{2} \mathrm{~S}_{2} \mathrm{O}_{3}$, $5 \mathrm{H}_{2} \mathrm{O}$ as 1:4. Integrated STS and essential oil treatments were prepared as shown in table one. $0.05 \mathrm{mM}$ STS was the basal amount for integrated treatments. Ethanol was employed to initially solubilize the essential oils. Vase solutions were exchanged every two-days and the essential oil containing treatments were replaced every three-days.

Table 1. Treatments

\begin{tabular}{|c|l|}
\hline Treatments & Content Solutions \\
& \\
\hline $\mathrm{T}_{1}$ & $0.05 \mathrm{mM}$ STS $+200 \mathrm{ppm}$ Satureja sahandica oil \\
$\mathrm{T}_{2}$ & $0.05 \mathrm{mM}$ STS $+200 \mathrm{ppm}$ Cupressus arizonica oil \\
$\mathrm{T}_{3}$ & $0.05 \mathrm{mM}$ STS $+200 \mathrm{ppm}$ Echinophora platyloba oil \\
$\mathrm{T}_{4}$ & $0.05 \mathrm{mM}$ STS $+200 \mathrm{ppm}$ Tanacetum balsamita oil \\
$\mathrm{T}_{5}$ & $0.1 \mathrm{mM}$ STS \\
\hline
\end{tabular}

\section{Traits:}

Soluble absorption rate, flower diameter and vase life were the main morphological traits assayed. Vase life was recorded at the day when $50 \%$ of petals were showing the wilting signs.

Soluble absorption rate was traced by the formula;

Soluble absorption rate $=V_{t}-V_{t-1} /$ stem weight at the day zero

Where $V_{t}$ refers to the vase soluble volume during the measurements, and $V_{t-1}$ is the soluble volume at the day before. This trait was recorded at one-day intervals up to end of vase life.

Flower diameter; a criterion showing the flower openness index was recorded at one-day intervals again at the end of vase life.

Malondialdehyde (MAD) content and hydrogen peroxide $\left(\mathrm{H}_{2} \mathrm{O}_{2}\right)$ were traced by
Sergive et al. (11), and membrane stability index by Sairum et al. (12).

\section{Statistical analyses:}

The experiment was conducted as CRD with three replications. The data were analyzed by SAS. Mean comparison were tried by LSD and the graphs were drown by Excel.

\section{RESULTS AND DISCUSSION}

ANOVA revealed the significant $(\mathrm{P} \leq 0.05)$ effects of integrated use of EOs and STS on vase life of 'Liberty' cut carnation flowers. $C$. arizonica and $T$. balsamita oils had the potential 50\% substitution of STS considering the most important postharvest trait i.e. vase life. S. sahendica and E. platiloba were not potentiate to be substituted with STS at the oil concentrations applied (Figure 1). The possible positive effects of $C$. arizonica and $T$. balsamita on vase life could be attributed to special constituents of EOs. Monoterpens are the predominant oil constituents with these tow oils. Carvone (a ketonic compound) is the 
major T. balsamita essential oil component (13). $\alpha$-Pinene, has been defined as the dominant hydrocarbon monoterpenic constituent of $C$. arizonica oil (14). There is evidence that biological activity of ketonic compounds is more than that of hydrocarbons (15). However, the biological activity of EOs is in main part due to the synergistic effects of several compounds and surly the same idea has been the reason for the effects of two oils on carnation vase life. Vase longevity is the main criterion affects the economic value of cut flowers. The vase life end in carnation is considered based on the visual signs of senescence such as external petals in-rolling, whole petals wilting and by peak ethylene production (1). There are controversy ideas on the effects of essential oil on vase life prolongation of cut flowers. Menta piperata, Thymus vulgaris and Carum carvi had no significant effects on cut carnation flowers longevity (16). In line, the same essential oils had negative effects on the vase life of alstromeria (17). Diverse cultivars show not similar responses to the treatments; for example 'Red explosion' and 'double dutch' gerbera cultivars had different vase life responses to thymol applications (18).

Overall, the positive effects of EOs applications on vase life of cut flowers have been attributed mainly to the biological activity of these compounds on microorganisms (9, 19). Integrated EOs and STS treatments hold both the biological activity of EOs and the anti-ethylene characteristics of STS. Jalili Marandi et al. (10) studied the effects of Caminum cyminum and Saturejia hortensis combined with STS on rose and gladiolus cut flowers and the combined Cuminum cyminum oil plus STS was the treatment of choice for the prolongation of gladiolus vase life.

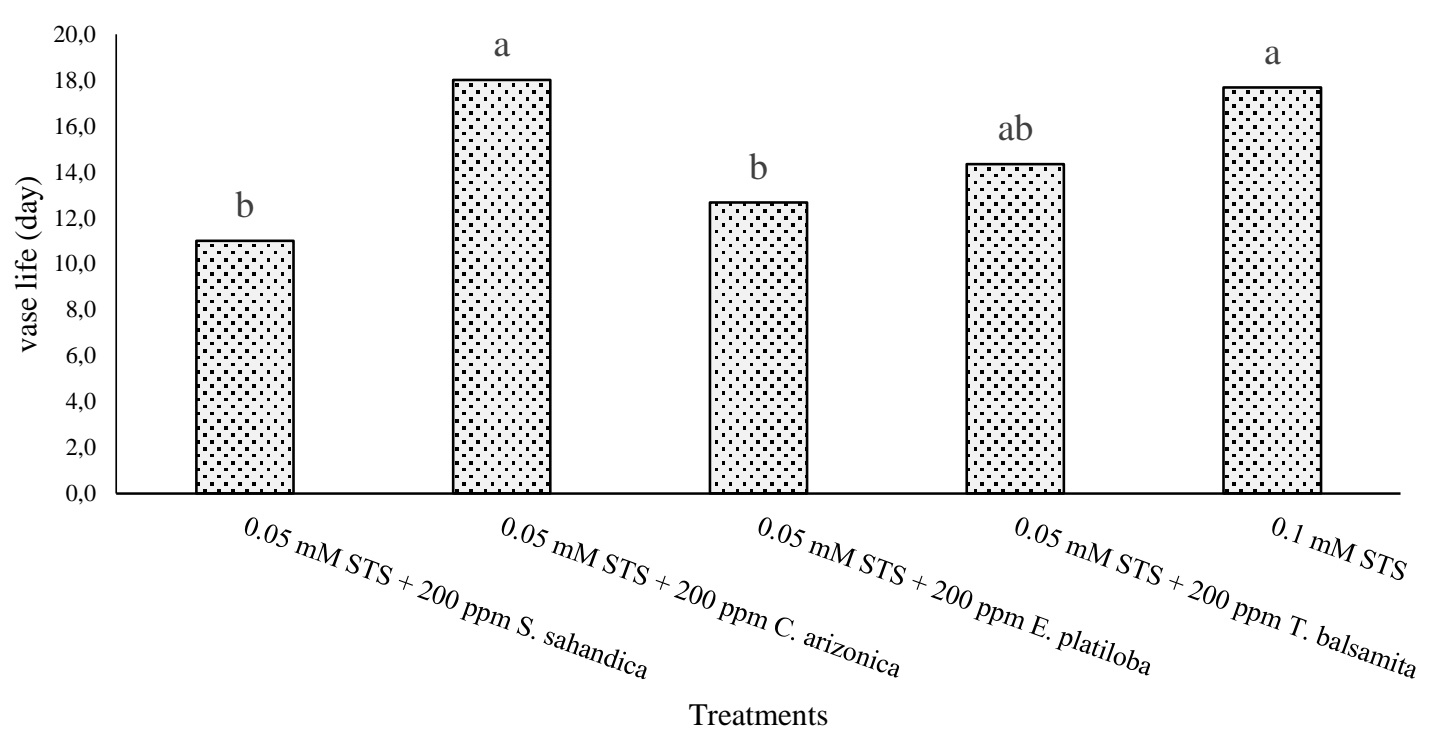

Figure 1. Integrated use of EOs and STS on vase life of 'Liberty' cut carnation flowers $(\mathrm{P} \leq 0.05)$

Mean comparisons revealed that flower diameter was affected by the treatment. 0.1 mM STS and combined STS and C. arizonica and $T$. balsamita had the same positive effect on flower diameter (Figure 2). Figure 3 shows that STS treatment was the best considering soluble absorption rate. The lowest data for the mentioned trait and even for vase life was belonged to $S$. sahendica + STS treatment. STS + costmary and cuppressus oil had quite positive effects on vase life, but, the effects on soluble absorption rate was much lower than singular application of STS. Contrarily, combined before mentioned treatments had higher flower diameter and flower visual freshness compared to singular STS usage. Possibly, the cut flowers had more soluble absorption in STS treatment. It seems that with the combined EOs and STS treatments, the equilibrium in absorption and transpiration affects the water loss in favor of longevity and vase life. 


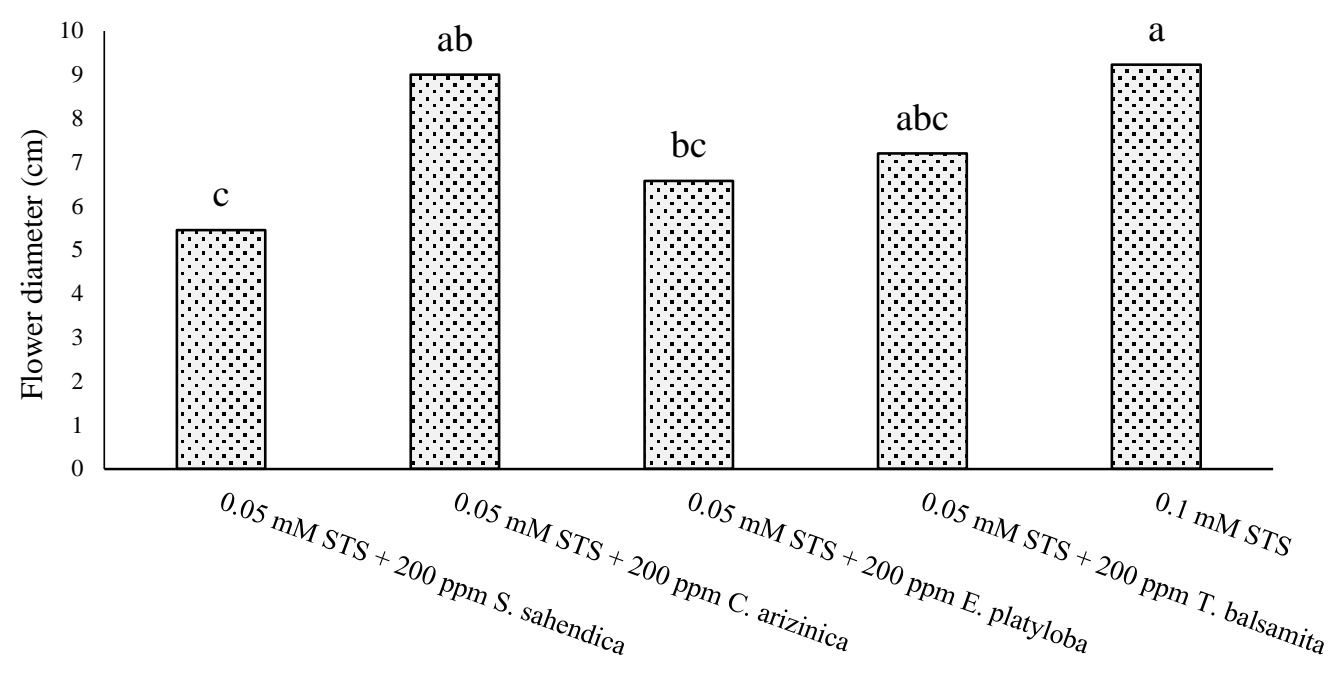

Treatments

Figure 2. Integrated use of EOs and STS on the flower diameter of cut carnation 'Liberty' flowers during postharvest $(\mathrm{P} \leq 0.05)$

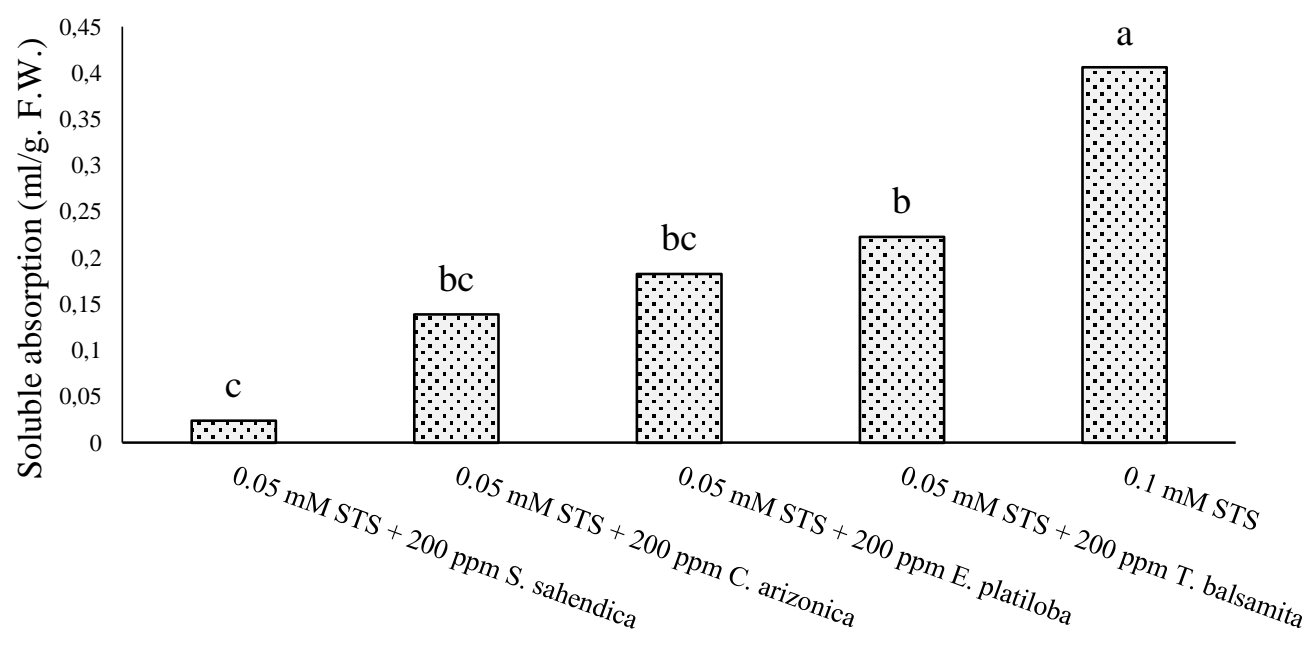

Treatment

Figure 3. Integrated use of EOs and STS on soluble absorption rate of cut carnation 'Liberty' flowers during postharvest $(\mathrm{P} \leq 0.01)$

Balanced equilibrium in water loss and absorption (water equilibrium) is the main factor influencing the quality and vase life of cut flowers. Obstacles in water intake drastically affects the water stream equilibrium leading to enhanced transpiration and hastened senescence in cut flowers and hence reduced vase life (9). Beside several physio-chemical factors affecting vessels (xylems) closure, some others such as gene-expression at the cellular and organ level and later several physiological and biochemical phenomena such as variation in cell metabolism influence the water intake and translocation within the plant tissue and eventually impact the several morphological and visual characteristics of the plant (20).

The effects of essential oils on the improvement and equilibration of water relations in cut carnation flowers was in line with the reports of Norouzi Khatibi et al. (9) in chrysanthemum and Mousavi Bazaz and Tehranifar (17) in alstromeria.

It seems that the oil components and the effects of some oil constituents on hydraulic conductance of stem vessels greatly affect the soluble absorption and later the vase life of cut flowers treated with oils + STS. The lowest 
soluble absorption rate was recorded with $S$. sahendica oil treatment. So, the idea is that Satureja oil with the dominancy of $\gamma$-terpinene $(42.2 \%)$ and carvacrol (32\%) (13) had no significant effect on soluble absorption of cut carnations.

Solgi et al. (21), in their comparison of thymol and carvacrol and also the oils from Thymus and Zataria reported that just thymol $\left(50 \mathrm{mgL}^{-1}\right)$ increased the vase life and soluble absorption of cut gerbera flowers. Moreover, $100 \mathrm{mgL}^{-1}$ of all the treatments increased the soluble intake and vase life of cut flowers and this eventually improves the positive effects of EOs on vase life longevity of flowers. Even though, the type and compositional content of oils have inevitable effects on the biological activity of oils.

\section{Treatment effects on some biochemical traits of cut carnation 'Liberty' flowers:}

Figure 4 and 5 shows that carnation petals under STS and STS $+C$. arizonica had the lowest incidence of ion leakage and MDA and $\mathrm{H}_{2} \mathrm{O}_{2}$ content. $S$. sahendica + STS treatment had the same effect on MDA and $\mathrm{H}_{2} \mathrm{O}_{2}$. In contrast, combined effects of E. platyloba and $T$. balsamita + STS attained the lowest membrane stability index and the highest data for MDA and $\mathrm{H}_{2} \mathrm{O}_{2}$. Any decrease in membrane integrity is related to the damages to the membranes induced by lipids peroxidation duo to increased amounts of $\mathrm{H}_{2} \mathrm{O}_{2}$ and MDA.

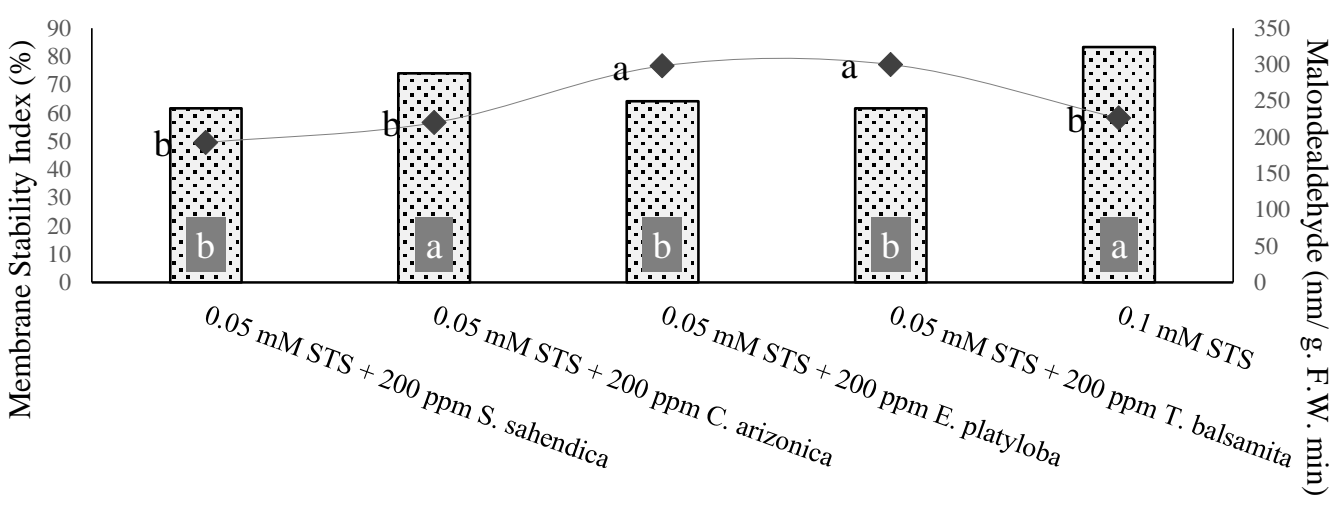

Treatments

$\because \because \mathrm{MSI}$

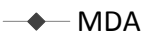

Figure 4. Integrated use of EOs with STS on membrane stability and MDA content in 'Liberty' cut carnation flowers $(\mathrm{P} \leq 0.01)$

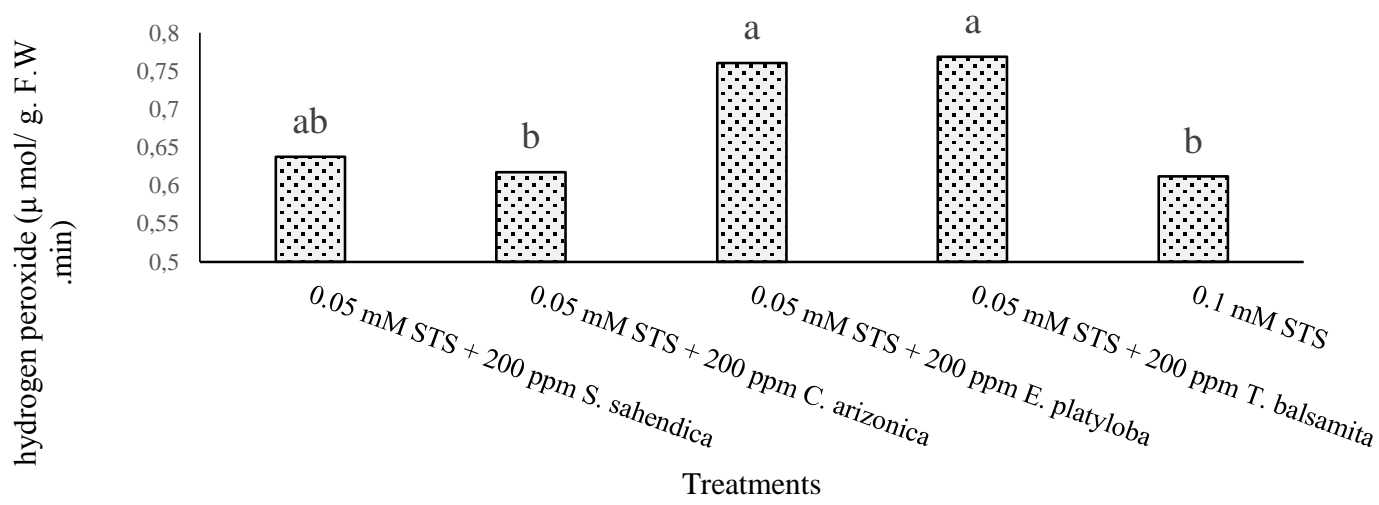

Figure 5. Integrated use of EOs and STS affect the $\mathrm{H}_{2} \mathrm{O}_{2}$ content in petals of cut carnation 'Liberty' flowers $(\mathrm{P} \leq 0.05)$

Lipids peroxidation goes to the deterioration of biological membranes and the result is variations in the rates of saturated to unsaturated fatty acids and MDA over- production. Depending on the MDA biosynthesis and release, the damage intensity of the membranes can be detected. Overproduction of MDA greatly intensifies the 
deterioration of plasma membranes (22) and the later side effects will be huge increase in membrane permeability and leakage (23).

Between the treatments tested, S. sahendica + STS had the high amounts of ion leakage in petal tissues and $\mathrm{H}_{2} \mathrm{O}_{2}$ over production both reflecting the highly damaged membrane lipids, but, the low accumulation of MDA. This may be explained by the fact that $S$. sahendica oil components had not enough antioxidant potential to scavenge the high amounts of $\mathrm{H}_{2} \mathrm{O}_{2}$ produced. Our results describe the low accumulation of MDA in $C$. arizonca + STS and STS alone and also the low incidence of $\mathrm{H}_{2} \mathrm{O}_{2}$ radicles, and hence, the high membrane integrity of the treatments. This means that the integrated use of $C$. arizonca oil with STS had the potential of controlling the high release of MDA and its related deteriorative effects and hence to ameliorate the membrane damage and minimally affect the membrane integrity and subsequently minimize the damages imposed on plant cell and tissues.

Considering, C. arizonca oil was a potentiate compound to increase the vase life, flower diameter and water relations in cut carnation flowers. Combined STS and cuppressus oil application could be proposed for the commercial postharvest handling and storage of carnation 'Liberty' cut flowers.

Noteworthy, $C$. arizonca is a commonly available urban and forest tree with a plenty of fruits and also high essential oil content. So, can be a good alternative for the partial substitution of STS.

\section{CONCLUSION}

Environmental and health limitations in the STS applications encourage the scientists to find some organic safe alternatives with reduced toxicity in the preservative solutions for cut flowers industry. Considering the good preservative characteristics of EOs and the direct results obtained from the present experiment, $C$. arizonca and $T$. balsamita oils would be good alternatives to substitute the $50 \%$ of STS amount in the postharvest storage of 'Liberty' carnation cut flowers. Taking into account the practicability of these treatments and the availability of these two plants and their high oil contents, they can be recommended for the extension sections to reduce the side damages of STS individual applications and to take the benefits of environment and health friend EOs in postharvest biology and quality ensuring of cut flowers.

\section{REFERENCES}

1. Ebrahimzadeh, A., Jimenez, S., da Silva, J.A., Satoh, S., and Teresa Lao, M. Postharvest physiology of cut carnation flowers. Fresh Produce (C). Global Science Books, 2:56-71, 2008.

2. AIPH. 2013. International statistics flowers and plants. Zentrum für Betriebswirtschaft im Gartenbau e.V. an der Leibniz Universität Hannover, Vol 61, 2013.

3. Porat, R., Shlomo, E., and Serek, M. 1Methylcyclopropene inhibitors ethylene action in cut phlox flowers. Postharvest Biol Tec, 6: 313-319, 1995.

4. Van Doorn, W.G., and Stead, A.D. Abscission of flowers and floral parts. Phyton-Int J Exp Bot, 48: 821-837, 1997.

5. Dorman, H.J.D., and Deans, S.G. Antimicrobial agents from plants: antibacterial activity of plant volatile oils. $J$ Appl Microbiol, 88: 308-316, 2000.

6. Dulce, M., Antunes, C., and Cavaco, M. The use of essential oils for postharvest decay control. A review. Flavour Frag J, 25: 351-366, 2010.

7. Tripathi, P., and Dubey, N.K. Exploitation of natural products as an alternative strategy to control postharvest fungal rotting of fruit and vegetables. Postharvest Biol Tec, 32: 235-245, 2004.

8. Siripornvisal, S., Rungprom, W., and Sawatdikarn, S. Antifungal activity of essential oils derived from some medicinal plants against grey mould (Botrytis cinerea). As J Food Ag-Ind., Special Issue: 229-233, 2009.

9. Norouzi Khatibi, M., Hashemabadi, D., and Shafie, M. Improvement vase life and postharvest quality of cut chrysanthemum (Dendranthema grandiflorum L.) by Eryngo Oil. Annals of Biological Research, 3: 5486-5489, 2012.

10.Jalili Marandi, R., Hassani, A., Abdollahi, A., and Hanafi, S. Improvement of the vase life of cut gladiolus flowers by essential oils, salicylic acid and silver thiosulfate. $J$ Med Plant Res, 5: 5039-5043, 2011.

11.Sergiv I., Alexieva V., and Karanov E. Effect of spermine, atrazine and combination between them on some endogenous protective systems and stress markers in plants. Comptes rendus de l'Académie bulgare des sciences, 51: 121124, 1997.

12.Sairam, R.K., Shukla, D.S., and Saxena, D.C. Stress induced injury and antioxidant enzymes in relation to drought tolerance in wheat genotypes. Biol Plantarum, 40: 357364, 1997. 
13.Hassanpouraghdam, M.B., Safi Shalamzari, M., Aazami, M.A., and Mohajjel shoja, A. $\gamma$-Terpinene and carvacrol rich volatile oil of Satureja sahendica Bornm. from Maragheh district in Northwest Iran. Chemija, 20: 186-189, 2009.

14.Hassanpouraghdam, M.B. $\alpha$-Pinene and $\beta$ myrcene rich volatile fruit oil of Cupressus arizonica Greene. from North-West Iran. Nat Prod Res, 25: 634-639, 2010.

15.Bassolé, H.N., and Juliani, H.R. Essential oils in combination and their antimicrobial properties. Molecules, 17: 3989-4006, 2012.

16. Karimian Fariman, Z., and Tehranifar, A. Effect of essential oils, ethanol and methanol to extend the vase-life of carnation (Dianthus caryophyllus L.) Flowers. J Biol Environ Sci, 5: 91-94, 2011.

17.Mousavi Bazaz, A., and Tehranifar, A. Effect of ethanol, methanol and essential oils as novel agents to improve vase-life of Alstroemeria flowers. J Biol Environ Sci, 5: 41-46, 2011.

18. Oraee, T., Asghar Zadeh, A., Kiani, M., and Oraee, A. The role of preservative
EBRAHIMZADEH A., et al. compounds on number of bacteria on the end of stems and vase solutions of cut gerbera. JOHP, 1: 161-165, 2011.

19. Shanan, N.T. Applications of essential oils to prolong the vase life of Rosa (Rosa hybrid L. cv.Grand) cut flowers. J Hort Sci \& Ornamen Plants, 4: 66-74, 2012.

20.Jones, B.R., and Hill, M. The effect of germicides on the longevity of cut flowers. J Amer Soc Hort Sci, 118: 350-354, 1993.

21.Solgi, M., Kafi, M., Taghavi, T.S., and Naderi, R. Essential oils and silver nanoparticles (SNP) as novel agents to extend vase-life of gerbera (Gerbera jamesonii cv. 'Dune') flowers. Postharvest Biol Tec, 53: 155-158, 2009.

22. Yoshimura, K., Yabuta, Y., Ishikawa, T., and Shigeoka, S. Expression of spinach ascorbate peroxidase isoenzymes in response to oxidative stresses. J Plant Physiol, 123: 223-233, 2000.

23.Kazemi, M., and Ameri, A. Response of vase-life carnation cut flower to salicylic acid, silver nanoparticles, glutamine and essential oil. Asian J Anim Sci, 6: 122-131, 2012. 